đa khoa có khoa điều trị ung thư trên địa bàn) cũng được chỉ ra là có tác động đến hoạt động quản lý thu chi của bệnh viện trong hiện tại cũng như trong tương lai.

\section{TÀI LIỆU THAM KHẢO}

1. Nurettin Oner (2016), Organizational and Environmental Factors Associated with Hospital Financial Performance: A Systematic Review
2. Nguyễn Thị Bích Hường (2012), Đánh giá một số kết quả sau 5 năm thực hiện tự chủ tài chính tại Bênh viên hữu nghi Viêtt Đ̇ức (2007-2011), Luân văn Thạc sĩ Trường Đại học Y tế công cộng, Hà Nội.

3. Nguyến Thi Nhan (2017), Kết quả hoạt đông thu chi tài chính tại Trung tâm Dich vụ Y tế Bệnh viên Đa khoa Tỉnh Khánh Hòa giai đoan 2014 - 2016

4. Global Cancer Statistics (2018), GLOBOCAN Estimates of Incidence and Mortality Worldwide for 36 Cancers in 185 Countries

\title{
NGHIÊN CỨU TỈ LÊ TYPE VIRUS DENGUE Ở BÊNNH NHÂN NHI TRONG MộT SỐ ĐợT DİCH TẠI KHU VỰC MIỀN NAM VIỆT NAM
}

\section{TÓM TẮT}

Mục tiêu: Phân tích tỉ lệ type huyết thanh virus Dengue ở bênh nhân nhi trong một số đợt dịch tai Thành phố Hồ Chí Minh, Tiền Giang và Đồng Nai. Đối tượng và phương pháp nghiên cứu: 344 bệnh nhân nhi được chẩn đoán sốt xuất huyết Dengue giai đoạn cấp tính trong vòng 3 ngày của sốt, được nhập viên điều tri tai khoa nhi bênh viên Nhi Đồng 1 , bênh viện Tiền Giang và bệnh viện Nhi Đồng Đồng Nai từ tháng 1-2011 đến tháng 12-2015.Tất cả các bênh nhân đều được thân nhân và người nhà đồng ý tham gia nghiên cứu. Tiến hành thu thập huyết thanh của bệnh nhân, tách RNA. Sử dụng phản ứng Multiplex RंT-PCR xác đinh các type huyết thanh của virus DENV. Kết quả: Bệnh nhân nhiếm type 1 (DENV-1), type 2 (DENV-2), type 3 (DENV-3) và type 4 (DENV4) chiếm tỉ lệ lần lượt là $34,01 \%, 19,77 \%, 5,52 \%$ và $40,70 \%$. Kết luận: Xuất hiện đủ cả 4 type huyết thanh virus Dengue ở các đợt dịch trong thời gian nghiên cứu, với type 4 (DENV-4) chiếm tỉ lệ cao nhất và thấp nhất là type 3 (DENV-3.

Tư khóa: virus dengue, type huyết thanh, nhi.

\section{SUMMARY}

INCIDENCE OF DENGUE VIRUS INFECTION IN PEDIATRIC PATIENTS IN SOME EPIDEMIC OUTBREAKS IN SOUTHERN VIETNAM

Objectives: To analyze the prevalence of dengue virus infection in pediatric patients in several epidemics in Ho Chi Minh City, Tien Giang, and Dong Nai provinces. Subjects and methods: 344 pediatric patients diagnosed with febrile dengue phase within three days of fever, admitted to the Department of Pediatrics at Children Hospital No.1 in Ho Chi Minh City, Tien Giang General Hospital and Dong Nai Children Hospital from January 2011 to December

'Bệnh viện Quân y 103

${ }^{2}$ Hoc viên Quân y

Chịu trách nhiệm chính: Đặng Thành Chung

Email: dangthanhchung@vmmu.edu.vn

Ngày nhận bài: 15.3.2021

Ngày phản biên khoa hoc: 10.5.2021

Ngày duyệt bài: 17.5.2021

\section{Nguyễn Đức Thuận', Đặng Thành Chung²}

2015, Participation in the study was voluntary and agreed to participate in the study by their relatives and family members. Carry out serum collection of the patient, RNA extraction. Using Multiplex RT-PCR reaction to determine dengue virus serotypes. Results: Patients infected with type 1 (DENV-1), type 2 (DENV-2), type 3 (DENV-3) and type 4 (DENV-4) accounted for $34.01 \%, 19,77 \%, 5.52 \%$ and $40.70 \%$ respectively. Conclusion: There are all four dengue virus serotypes in outbreaks during the study period, with Type 4 (DENV-4) has the highest proportion, and the lowest is type 3 (DENV-3).

Key words: dengue virus, serotypes, pediatric.

\section{I. ĐẶT VẤN ĐỀ}

Hiện nay virus Dengue lưu hành và gây dịch tại trên 100 quốc gia và vùng lãnh thổ chủ yếu ở vùng nhiệt đới như Đông Nam Á, Tây Thái Bình Dương, Châu Phi, Châu Mỹ, Địa Trung Hải. Nhiều nghiên cứu đã cho thấy rằng sau khi đi du lịch thì sốt xuất huyết dengue (SXHD) là nguyên nhân gây sốt phổ biến thứ 2 trong các bệnh nhiệt đới sau sốt rét [1]. Tỉ lệ nhiếm virus Dengue (DENV) đã tăng đáng kể trên toàn thế giới trong thập kỷ gần đây, với ước tính khoảng 3,9 tỉ người trong số 128 quốc gia có nguy cơ bị nhiễm virus Dengue. Trong những năm 2010, 2013 và 2015 có khoảng 2,4 triệu người bị nhiễm hàng năm [1]. Có 4 type virus dengue xuất huyết. Tất cả các type này đều gây bệnh sốt dengue (DF) và SXHD. Bệnh SXHD gần như xảy ra trên toàn cầu và bao trùm một vùng với dân số khoảng 2.5 tỷ người - 40\% dân số thế giới. Theo thông báo của Tổ chức $Y$ tế Thế giới (WHO), có từ 50 đến 100 triệu ca bệnh mỗi năm [2].

Tại việt Nam trường hợp SXHD đầu tiên được phát hiên ở Đà Nẳng năm 1958 [3], cho đến nay tất cả bốn type virus của virus DENV đã được thấy lưu hành với ưu thế khác nhau của từng type là khác nhau theo thời gian. Theo các báo cáo từ Viện vệ sinh dịch tễ Trung ương cho 
thấy DENV-1 và DENV-2 là những type chiếm ưu thế và lưu hành hầu như hàng năm. DENV-3 xuất hiện vào cuối thập niên 1990 và là type ưu thế trong đợt bùng phát dịch năm 1998, trong khi túyp DENV-4 cũng được phát hiện trong khoảng từ năm 1999-2003. Hiện nay, SXHD ngày càng gia tăng với tốc độ cao, nhất là ở miền Nam. Tình hình nhiễm sốt xuất huyết ở Viêt Nam không ổn đinh nhưng thời kỳ cao điểm của dịch sốt xuất huyết là từ tháng 6 đến tháng 10 hàng năm. Tỷ lệ mắc sốt xuất huyết trên 100000 dân dao động 148,1 năm 2010, 80,4 năm 2011, 94,2 năm 2012 và 91,6 năm 2013 [4]. Năm 2010, đã có 113 người tử vong do sốt xuất huyết, đến năm 2013 số tử vong khoảng 60 người. Trên $85 \%$ ca mắc và $90 \%$ ca tử vong do sốt xuất huyết là ở các tỉnh miền Nam Việt Nam. Mặc dù không có con số chính thức về tỷ lệ mắc SXHD ở trẻ em, nhưng theo báo cáo của Bộ y tế năm 2014 cho biết, khoảng $90 \%$ số ca tử vong do sốt xuất huyết là ở nhóm tuổi dưới 15 [4].

Ở nghiên cứu này chúng tôi tiến hành thống kê tỉ lệ type virus dengue trên bệnh nhân nhi trong một số đợt dịch tại khu vực miền nam Việt Nam.

\section{II. ĐỐI TƯợNG VÀ PHƯƠNG PHÁP NGHIÊN CỨU}

2.1 Đối tượng nghiên cứu: 344 bệnh nhân nhi được chẩn đoán sốt xuất huyết Dengue giai đoạn cấp tính trong vòng 3 ngày của sốt, được nhâp viên điều trị tai khoa nhi bênh viên $\mathrm{Nhi}$ Đồng 1 , bệnh viện Tiền Giang và bệnh viện Nhi Đồng Đồng Nai từ tháng 1-2011 đển tháng 122015.Tất cả các bệnh nhân đều được thân nhân và người nhà đồng ý tham gia nghiên cứu.

2.2 Phương pháp nghiên cứu: Mẫu máu của các bệnh nhân được bảo quản lạnh và chuyển tới trung tâm xét nghiệm của bệnh viện để tách huyết thanh bằng máy li tâm lanh. Tất cả các mẫu được bảo quản trong đông sầu $-80^{\circ} \mathrm{C}$ cho đến khi tiến hành tách RNA. Mẫu huyết thanh của bệnh nhân được tiến hành tách RNA sử dụng kit tách chiết RNA từ virus của Hàn Quốc "GeneAll ExgeneTM Viral DNA/RNA" (GeneAll, 128-150). Quy trình tách được thực hiện theo hướng dấn của nhà sản xuất.

Lựa chọn mồi (primers) để xác định các type virus của virus DENV: Các bộ mồi khác nhau để xác định type virus của virus DENV được tìm kiếm dựa trên các nghiên cứu trước đó theo tiêu chí để đảm bảo đặc hiệu, độ nhạy, khả năng tương thích, khác nhau về kích thước sản phẩm PCR (amplicon), thành phần guanine-cytosine, kích cõ mồi và nhiệt độ biến tính. Trong nghiên cứu này chúng tôi lựa chọn bộ mồi để định type virus của virus DENV dựa trên nghiên cứu của Lanciotti và cộng sự [5]. Được tóm tắt theo bảng sau:

\begin{tabular}{|c|c|c|c|}
\hline $\begin{array}{c}\text { Type } \\
\text { virus }\end{array}$ & Mồi & Trình tự mòi & $\begin{array}{c}\text { Kích thước sản phẩm } \\
\text { PCR }\end{array}$ \\
\hline & Dcon & 5'-TCAATATGCTGAAACGCGCGAGAAACCG-3' $^{\prime}$ & \\
\hline DENV-1 & D1 & 5'-CGTCTCAGTGATCCGGGGG-3' $^{\prime}$ & $482 \mathrm{bp}$ (Dcon\&D1) \\
\hline DENV-2 & D2 & 5'-CGCCACAAGGGCCATGAACAG-3' $^{\prime}$ & $119 \mathrm{bp}$ (Dcon\&D2) \\
\hline DENV-3 & D3 & 5'-TAACATCATCATGAGACAGAGC-3' $^{\prime}$ & $290 \mathrm{bp}$ (Dcon\&D3) \\
\hline DENV-4 & D4 & 5'-CTCTGTTGTCTTAAACAAGAGA-3' $^{\prime}$ & $392 \mathrm{bp}$ (Dcon\&D4) \\
\hline
\end{tabular}

Dcon: dengue conserved region.

Phản ứng Multiplex RT-PCR xác định các type virus của virus DENV: $5 \mu \mathrm{L}$ của RNA tách từ huyết thanh của bệnh nhân được khuếch đại trong $50 \mu \mathrm{L}$ hốn hợp phản ứng với $0.5 \mathrm{mM}$ mồi upstream Dcon và bốn mồi downstream đặc hiệu cho type virus của virus DENV (D1-D4) sử dụng OneTaq One-step RT-PCR Kit (NEB, E5315S), là kit kết hợp 2 bước tạo cDNA và khuếch đại PCR trong cùng một phản ứng, qui trình tuân theo hướng dẫn của nhà sản xuất. Ống PCR được li tâm ngắn, phản ứng phiên mã ngược được thực hiện với một chu kỳ tại $50^{\circ} \mathrm{C}$ trong 30 phút, sau đó phản ứng khuếch đại $\mathrm{PCR}$ với 35 chu kỳ theo chu trình nhiệt như sau $\left(95^{\circ} \mathrm{C}\right.$ trong 30 giây, $55^{\circ} \mathrm{C}$ trong 45 giây và $72^{\circ} \mathrm{C}$ trong 2 phút). Kích thước của sản phẩm PCR thu được sẽ đă̆c hiêu cho từng type virus khác nhau của virus DENV, ví dụ 482 bp cho DENV-1; 119 bp cho DENV-2; 290 bp cho DENV-3 và 392 bp cho DENV-4. Được xác định thông qua điện di sử dụng gel Agarose $2 \%$ và hệ thống đọc gel kỹ thuật số (Alpha Innotech, San Leandro, CA).

Sau khi các thông tin và số liệu đã được thu thập đầy đủ tiến hành phân tích trình bày dưới dạng tần suất và tỷ lệ phần trăm.

\section{KẾT QUẢ NGHIÊN CỨU}

Chúng tôi sử dụng kỹ thuật Multiplex Reverse-Transcriptase PCR trong xác định týp virus Dengue, kết quả của một lần chạy RT-PCR được minh họa dưới hình sau: 


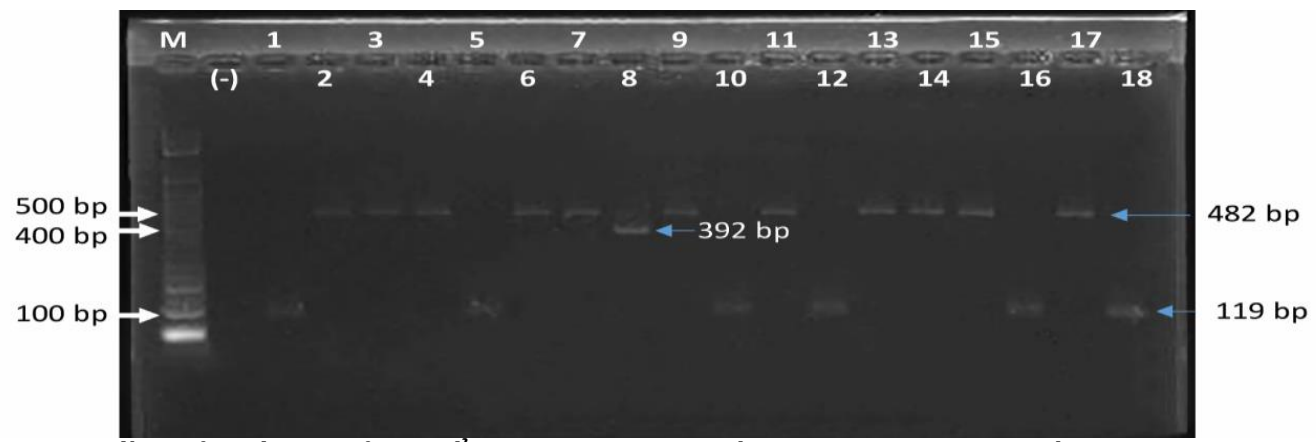

Hình 1: Kết quả điện di sản phẩm RT-PCR định týp virus Dengue. M là 50 bp molecular marker; (-) là chứng âm không có RNA; (1-18) mã bệnh nhân cần xác định tuýp huyết thanh, band đặc hiệu cho các tuýp huyêt thanh cu thế DENV-1 (482 bp); DENV-2 (119 bp); DENV-4 (392 bp)

Bảng 1. Phân bố bệnh nhân theo type virus của virus Dengue

\begin{tabular}{|c|c|c|c|c|c|}
\hline & DENV-1 & DENV-2 & DENV-3 & DENV-4 & Tống số \\
\hline Số bệnh nhân & 117 & 68 & 19 & 140 & 344 \\
\hline$\%$ & 34,01 & 19,77 & 5,52 & 40,70 & 100,00 \\
\hline
\end{tabular}

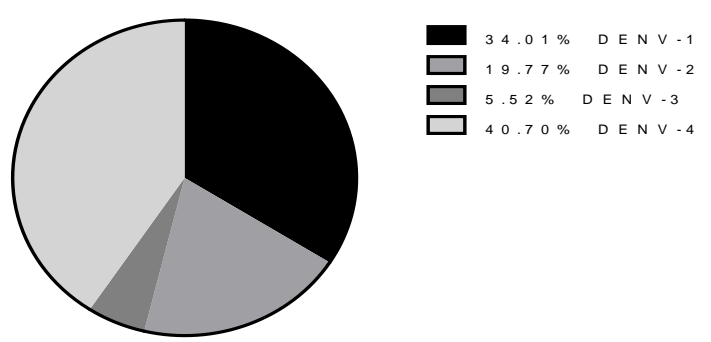

Hình 2. Đồ thị biểu diễn tỉ lệ phân trăm bệnh nhân theo các type virus của virus Dengue trên tổng số bệnh nhân.

Kết quả cho thấy số bệnh nhân nhiễm type 4 (DENV-4) chiếm tỉ lệ cao nhất là $40,70 \%$ và thấp nhất là type3 chiếm tỉ lệ 5,52\%.

\section{BÀN LUÂ̂N}

Trong số 344 trường hợp được chẩn đoán dương tính và định type virus của virus Dengue bằng kỹ thuật "Real-time multiplex reverse transcription - PCR" kết quả cho thấy xuất hiện cả 4 type virus ở đối tượng tham gia nghiên cứu, trong đó DENV-4 chiếm tî lệ cao nhất $(40,70 \%)$ DENV-1 $(34,01 \%), \mathrm{DENV}-2(19,77 \%)$ và thấp nhất là DENV-3 (5,52\%).

Cho đến nay tất cả bốn type virus của virus DENV đã được thây lưu hành tại Việt Nam, với ưu thế khác nhau của từng type là khác nhau theo thời gian. Theo các báo cáo từ Viện vệ sinh dịch tễ Trung ương cho thãy DENV-1 và DENV-2 là những type chiếm ưu thế và lưu hành hầu như hàng năm. DENV-3 xuất hiện vào cuối thập niên 1990 và là type ưu thế trong đợt bùng phát dịch năm 1998, trong khi túyp DENV-4 cũng được phát hiện trong khoảng từ năm 1999-2003 [6]. Theo một nghiên cứu khác được tiến hành tại
Bình Thuận trong giai đoạn từ năm 2001 đến 2006 cho thấy type DENV-4 chiếm ưu thế trong giai đoạn 2001 đến 2002, type DENV-1 và DENV2 chiếm ưu thế trong giai đoạn 2003-2006, và chỉ có duy nhất một trường hợp type DENV-3 được xác định trong giai đoạn đó [7]. Theo Takamatuse và cộng sự tiến hành nghiên cứu vụ dịch lớn xảy tại khu vực miền Trung vào năm 2013 cho thấy xuất hiện cả 4 type virus, trong đó type DENV-4 là chủ đạo chiếm 48,9\%, tiếp sau là DENV-1 chiếm $28,1 \%$, DENV-3 chiếm $12,6 \%$ và cuối cùng là DENV-2 chiếm $10,4 \%$ [8]. Cũng theo nghiên cứu này có sự gia tăng đến 20 lần những trường hợp nhiễm type DENV-4 vào năm 2013 so với nằm 2012, với tỉ lệ DENV-4 tăng từ 22,6\% (năm 2012) lên 48,9\% (năm 2013 [8]. Tuy nhiên sự phân bố các type virus còn phụ thuộc nhiều vào địa lý và lãnh thổ, trong một khảo sát của Halsey và cộng sự trong khoảng thời gian từ 2005-2010 tại một số nước như Peru, Bolivia, Ecuador và Paraguay cho kết quả DENV-1 (39.8\%), DENV-2 (4.3\%), DENV-3 $(41.5 \%)$, và DENV-4 (14.4\%). Như vậy DENV-3 và DENV-1 chiếm ưu thế vượt trội, trong khi DENV-2 và DENV-4 chiếm tỉ lệ khá nhỏ.

Trong nghiên cứu này của chúng tôi DENV-4 chiếm ưu thế, điều này cũng phù hợp với xu hướng phát triển mạnh mẽ của type này trong thời gian gần đây tại Việt Nam. Có một vài giả thuyết được đưa ra để giải thích cho sự tăng đột ngột của DENV-4 như: có đột biến gen của type này để thích ứng với vật chủ, hoặc do sự thay đổi về miễn dịch của cộng đồng dân cư ở đây... [8].

\section{KẾT LUẬN}

Xuất hiện đủ cả 4 type huyết thanh virus 
Dengue ở các đợt dịch trong thời gian nghiên cứu, với type 4 (DENV-4) chiếm tỉ lệ cao nhất và thấp nhất là type 3 (DENV-3.

Bệnh nhân nhiễm type 1 (DENV-1), type 2 (DENV-2), type 3 (DENV-3) và type 4 (DENV-4) chiếm tî lệ lần lượt là $34,01 \%, 19,77 \%, 5,52 \%$ và $40,70 \%$.

\section{TÀI LIÊU THAM KHẢO}

1. Rigau-Pérez JG, Vorndam AV, and Clark GG, The dengue and dengue hemorrhagic fever epidemic in Puerto Rico, 1994-2005. American Journal of Tropical Medicine and Hygiene, 2011. 64: p. $67-74$.

2. Trương Quang Học and cộng sự, Đánh giá các tác động không mong muổn có thể xảy ra khi phóng thả muối Aedes aegypti mang Wolbachia nhằm phòng chống Sốt xuất huyết tại Việt Nam. Dự án Ngăn chặn Sốt xuất huyết tại Việt Nam, 2011: p. 5 - 11.

3. WHO, Update on the Dengue situation in the
Western Pacific Region. Dengue Situation Update Number 467, 2015: p. 5 page.

4. Bộ Y tế, Quyết định 3711 QĐ-BYT ngày 19 tháng 9 năm 2014 của Bô trưởng Bố y tế về việc ban hành "Hướng dẫn giám sát và phòng, chống bệnh sốt xuất huyết Dengue". 2014.

5. Lanciotti R. S., et al., Rapid detection and typing of dengue viruses from clinical samples by using reverse transcriptase-polymerase chain reaction. $]$ Clin Microbiol, 1992. 30(3): p. 545-51.

6. NIHE, Final Report on evaluation of communicable diseases surveillance system in Vietnam 2008. 2009, National Institute of Hygiene and Epidemiology: Hanoi.

7. Thai K. T., et al., Clinical, epidemiological and virological features of Dengue virus infections in Vietnamese patients presenting to primary care facilities with acute undifferentiated fever. J Infect, 2010. 60(3): p. 229-37.

8. Takamatsu Y., et al., A Dengue virus serotype 4dominated outbreak in central Vietnam, 2013. ] Clin Virol, 2015. 66: p. 24-6.

\section{ĐĂC ĐIỂM LÂM SÀNG VÀ CÁC YẾU TỐ LIÊN QUAN ĐẾN SỞI Có BIẾN CHỨNG Ở TRẺ EM TẠI BỆNH VIỆN NHI ĐÔNGG CẦN THO'}

\section{TÓM TẮT}

Đặt vấn đề: Sởi là một bệnh truyền nhiễm cấp tính gây ra do virus sởi. Bệnh thường diễn biến lành tính, tuy nhiên tỉ lệ sởi có biến chứng vẫn còn cao. Mục đích của nghiển này nhằm mô tả các đăc điểm lâm sàng và xác định các yếu tố liên quan đến bệnh sởi có biến chứng ở trẻ em. Phương pháp và đối tượng nghiên cứu: Mô tả cắt ngang các trường họp mắc sởi với xét nghiệm Mac-Elisa $\operatorname{IgM}(+)$, nhâp viển tại Bệnh viện Nhi đồng Cần Thơ từ 1/2020 đến 6/2021 Kết quả: Tổng công có 144 trẻ mắc sởi từ 2-60 tháng, tuổi trung vị là 12 tháng, nam chiếm tỉ lệ $58 \%$. Trẻ chưa tiêm chủng sởi chiếm $81,3 \%$. Triêu chứng lâm sàng gồm sốt (100\%), phát ban (100\%), ho $(97,9 \%)$, dấu Koplik $(54,0 \%)$ và nôn ói $(29,2 \%)$. Tỉ lệ sởi có biến chứng là $47,9 \%$. Hai biến chứng hay găp là viêm phổi $(21,5 \%)$ và viêm da dày ruôt $(22,9 \%)$. Các yếu tố có liên quan đến sởi có biển chứng gồm chưa tiêm chủng ( $O R=5,57 ; p=0,022)$, CRP tăng $(\mathrm{OR}=1,08 ; \mathrm{p}=0,027)$ và nôn ói $(\mathrm{OR}=3,05$; $\mathrm{p}=0,036)$. Kết luân: Bệnh sởi thường gặp ở trẻ dưới 12 tháng tuổi, chưa được tiêm chủng. Hai biến chứng hay gặp là viêm phổi và tiêu chảy. Không tiêm chủng, CRP tăng và có nôn ói là các yếu tố có liên quan với bênh sởi có biến chứng.

Tư khóa: Sởi, trẻ em, biến chứng

${ }^{1}$ Trường Đại học Y Dược Cần Thơ

Chịu trách nhiệm chính: Nguyễn Ngọc Rạng

Email: nguyenngocrang@gmail.com

Ngày nhận bài: 16.3.2021

Ngày phản biên khoa hoc: 11.5.2021

Ngày duyệt bài: 18.5.2021
Nguyễn Ngọc Rạng¹, Phan Đặng Trang Đài ${ }^{1}$

SUMMARY

CLINICAL CHARACTERISTICS AND

FACTORS ASSOCIATED WITH MEASLES COMPLICATION IN CHILDREN AT CAN THO CHILDREN'S HOSPITAL

Background: Measles is an acute infectious disease caused by measles virus. The disease usually has a benign course, but measles complications are still high. The aim of this study was to describe the clinical features and identify factors associated with complicated measles in children. Methods and subjects: Cross-sectional description of cases of measles with Mac-Elisa IgM $(+)$, hospitalized at The Can Tho Children's Hospital from 1/2020 to 6/2021 Result: A total of 144 children with measles aged 260 months, median age was 12 months, male accounted for $58 \%$. Unvaccinated children accounted for $81.3 \%$. Clinical symptoms included fever $(100 \%)$, rash $(100 \%)$, cough (97.9\%), Koplik's spot (54.0\%) and vomiting $(29.2 \%)$. Two common complications were pneumonia (21.5\%) and gastroenteritis $(22.9 \%)$. Factors associated with complicated measles included unvaccinated $(\mathrm{OR}=5.57 ; \mathrm{p}=0.022)$, increased CRP (OR=1.08; $p=0.027)$ and vomiting ( $O R=3.05$; $p=0.036)$. Conclusion: Measles was common in unvaccinated children aged under 12 months. Pneumonia and gastroenteritis were 2 common complications. Unvaccinated, elevated CRP, and vomiting were the factors associated with complicated measles.

Keywords: Measles, children, complication

\section{I. ĐĂTT VẤN ĐỀ}

Sởi là một bệnh truyền nhiễm cấp tính gây ra 